\title{
Meningkatkan Prestasi Belajar Matematika Melalui Penggunaan Model Pembelajaran Problem Solving
}

\section{Dewa Nyoman Alit Biantara*}

SD Negeri 2 Kenderan

\author{
A R T I C L E I N F O \\ Article history: \\ Received 12 February \\ 2020 \\ Received in revised form \\ 18 March 2020 \\ Accepted 30 April 2020 \\ Available online 27 May \\ 2020 \\ Kata Kunci: \\ Model Pembelajaran \\ Problem Solving, Prestasi \\ Belajar \\ Keywords: \\ Problem Solving Learning \\ Model, Learning \\ Achievement
}

\begin{abstract}
A B S T R A K
Penelitian ini dilaksanakan di SD Negeri 2 Kenderan di kelas VI yang kemampuan siswanya untuk mata pelajaran Matematika masih rendah. Tujuan penulisan penelitian tindakan kelas ini adalah untuk mengetahui apakah prestasi belajar siswa dapat ditingkatkan dengan menerapkan langkah-langkah model pembelajaran Problem Solving. Metode pengumpulan datanya adalah tes prestasi belajar. Metode analisis datanya adalah deskriptif. Hasil yang diperoleh dari penelitian ini adalah prestasi belajar siswa dapat ditingkatkan dengan menerapkan langkah-langkah model pembelajaran Problem Solving. Ini terbukti dari hasil yang diperoleh pada awalnya 68,09 pada siklus I meningkat menjadi 72,61 dan pada Siklus II meningkat menjadi 80,95. Jadi, prestasi belajar Matematika siswa kelas VI SD Negeri 2 Kenderan dapat ditingkatkan dengan menerapkan langkah-langkah model pembelajaran Problem Solving.
\end{abstract}

\section{A B S T R A C T}

This research was carried out in SD Negeri 2 Kenderan in class VI where students' abilities in mathematics were still low. The purpose of writing this class action research is to find out whether student achievement can be improved by applying the steps of the Problem Solving learning model. The data collection method is a learning achievement test. The data analysis method is descriptive. The results obtained from this study are student achievement can be improved by applying the steps of the Problem Solving learning model. This is evident from the results obtained initially at 68.09 in the first cycle increased to 72.61 and in Cycle II increased to 80.95. The conclusion obtained from this study is that Mathematics learning achievement of Grade VI students of SD Negeri 2 Kenderan can be improved by applying the steps of the Problem Solving learning model. 


\section{Pendahuluan}

Pendidikan memegang peranan penting dalam mempersiapkan sumber daya manusia yang berkualitas dan mampu berkompetisi dalam perkembangan ilmu pengetahuan dan teknologi, sehingga pendidikan harus dilaksanakan dengan sebaikbaiknya untuk memperoleh prestasi belajar yang maksimal. Hal tersebut dapat dicapai dengan terlaksananya pendidikan yang tepat waktu dan tepat guna untuk mencapai tujuanp pembelajaran. Pembelajaran matematika di sekolah merupakan salah satu komponen pendidikan yang tidak hanya mengembangkan kemampuan dan keterampilan menerapkan matematika, melainkan mengembangkan kemampuan memecahkan masalah (Wijayanti, 2014).

Pendidikan merupakan bagian yang sangat penting dalam proses pembangunan suatu bangsa dan negara, karena tanpa didukungnya pendidikan tidak mungkin pembangunan suatu bangsa dan negara dapat berkembang dengan baik. Kita dapat melihat contohnya yaitu perkembangan antara desa dengan kota, dimana kota bisa dianggap lebih berkembang dari pada desa dikarenakan sistem pembangunan yang dipimpin oleh orang-orang terpelajar. Pendidikan itu sebenarnya harus didapatkan oleh setiap lapisan masyarakat agar pembangunan suatu bangsa dan negara itu dapat berjalan dengan baik. Hal tersebut juga terlihat dalam UUD 1945 pasal 31 yang menyatakan bahwa setiap warga negara berhak mendapatkan pendidikan (Amandemen UUD 1945, Bab XIII tentang Pendidikan dan Kebudayaan). Pernyataan dalam pasal 31 itu sekaligus merupakan landasan dan jaminan bagi setiap warga negara Indonesia untuk memperoleh pendidikan tanpa membedakan suku, agama, dan golongan (Sirait, 2016).

Di dalam Undang-Undang No. 20 tahun 2003 tentang Sistem Pendidikan Nasional, bab 1 pasal 1 dikemukakan "Pendidikan adalah upaya sadar dan terencana untuk mewujudkan suasana belajar dan proses pembelajaran agar peserta didik secara aktif mengembangkan potensi dirinya untuk memiliki kekuatan spiritual keagamaan, pengendalian dirinya, kepribadian, kecerdasan, akhlak mulia, serta keterampilan yang diperlukan dirinya, masyarakat, bangsa dan negara." (Undang Undang Sistem Pendidikan Nasional, 2009). Dewi Salma (Prawiradilaga, 2007). mengatakan tentang belajar "proses berfikir, terjadi secara internal didalam diri seorang untuk memahami dan mendalami suatu kemampuan atau kompetensi atau keahlian tertentu baik yang kasat mata maupun yang abstrak". Prestasi belajar merupakan hasil belajar yang dicapai setelah melalui proses kegiatan belajar mengajar. Prestasi belajar dapat ditunjukkan melalui nilai yang diberikan oleh seorang guru dari jumlah bidang studi yang telah dipelajari oleh peserta didik. Setiap kegiatan pembelajaran tentunya selalu mengharapkan akan menghasilkan pembelajaran yang maksimal.

Dalam proses pencapaiannya, prestasi belajar sangat dipengaruhi oleh berbagai faktor. Salah satu faktor utama yang sangat berpengaruh dalam keberhasilan pembelajaran adalah keberadaan guru. Mengingat keberadaan guru dalam proses kegiatan belajar mengajar sangat berpengaruh, maka sudah semestinya kualitas guru harus diperhatikan (Mulyasa, 2005). Hasil Belajar merupakan penilaian pendidikan tentang perkembangan dan kemajuan murid berkenaan dengan penguasaan bahan pengajaran yang disajikan kepada mereka serta nilai-nilai yang terdapat dalam kurikulum. Sumarni dan Bimo Budi Santoso serta Achmad Rantes Suparman dalam penelitiannya tentang hasil belajar dalam aspek kognisi menyimpulkan "Hasil penelitian menunjukkan bahwa ada perbedaan hasil belajar kognitif, model pembelajaran inkuiri terbimbing lebih baik dari model pembelajaran konvensional dengan persen pengaruh 29,49\% (Achmad Rantes, 2017) (Syafi'I, 2018).

Guru merupakan pihak yang berhubungan langsung dengan siswa. Sehingga dalam memberikan evaluasi diharapkan lebih akurat, objektif, dan mengoptimalkan pembelajaran. Masalah yang dihadapi misalnya masalah kepribadian guru dan kompetensi, kecakapan mengajar, yang antara lain mencakup ketepatan pemilihan metode pendekatan, motivasi, improvisasi, serta evaluasi. Disamping guru, orang tua juga merupakan pihak yang berperan utama dalam penanganan anak. Sebab interaksi anak dengan orang tua tetap lebih besar porsinya dibanding dengan interaksi guru dengan anak di sekolah. Orang tua harus mampu menciptakan kondisi dan menyediakan sarana yang menunjang proses belajar anak.

Menurut Aunurrahman, (2009: 176) keberhasilan proses pembelajaran merupakan muara dari seluruh aktivitas yang dilakukan guru dan siswa, artinya apapun bentuk kegiatan-kegiatan guru mulai dari merancang pembelajaran, memilih dan menentukan materi, pendekatan, strategi dan metode pembelajaran, memilih dan menggunakan teknik evaluasi semua disarankan untuk mencapai keberhasilan belajar siswa.

Namun demikian, kenyataan yang terjadi di lapangan sangat jauh dari harapan kita semua. Prestasi belajar Matematika siswa di SD Negeri 2 Kenderan sangat jauh dari nilai KKM yang ditentukan untuk mata pelajaran ini yaitu 73. Nilai rata-rata siswa 68,09 dan prosentase ketuntasan mata pelajaran Matematika pada siswa kelas VI semester II tahun pelajaran 2017/2018 hanya 47,61\%. 
Melihat kenyataan ini, peneliti dalam hal ini adalah guru di sekolah ini harus melakukan pembenahan strategi pembelajaran untuk memperbaiki prestasi belajar Matematika khususnya.

Mata pelajaran Matematika adalah mata pelajaran untuk pengembangan intelektual sosial dan emosional siswa serta berperan sebagai kunci penentu menuju keberhasilan dalam mempelajari bidangbidang yang lain. Untuk itu peneliti melaksanakan pembelajaran dengan penerapan langkah-langkah model pembelajaran Problem Solving. Menurut Purwanto (1999:17) Problem solving adalah suatu proses dengan menggunakan strategi, cara, atau teknik tertentu untuk menghadapi situasi baru, agar keadaan tersebut dapat dilalui sesuai keinginan yang ditetapkan. Sedangkan menurut Gulo (2002: 111) menyatakan bahwa problem solving adalah metode yang mengajarkan penyelesaian masalah dengan memberikan penekanan pada terselesaikannya suatu masalah secara menalar. Menurut Djamarah (2006: 103) bahwa, Model pembelajaran problem solving (metode pemecahan masalah) bukan hanya sekedar metode mengajar tetapi juga merupakan suatu metode berfikir, sebab dalam problem solving dapat menggunakan metode lain yang dimulai dari mencari data sampai kepada menarik kesimpulan.

Berdasarkan pemaparan di atas, maka dalam penelitian ini akan mengambil judul tentang Meningkatkan Prestasi Belajar Matematika Melalui Penggunaan Model Pembelajaran Problem Solving Pada Siswa Kelas VI SD Negeri 2 Kenderan Semester II Tahun Pelajaran 2017/2018.

Hipotesis yang dapat dirumuskan pada penelitian ini adalah jika langkah-langkah pembelajaran Problem Solving dimulai dengan hal-hal yang mudah untuk dipecahkan yang disesuaikan dengan langkahlangkah pembelajaran Problem Solving, maka prestasi belajar Matematika siswa kelas VI SD Negeri 2 Kenderan Semester II Tahun Pelajaran 2017/2018 akan dapat ditingkatkan.

\section{Metode}

Dalam melaksanakan Penelitian Tindakan Kelas, langkah-langkah atau prosedur PTK didasarkan pada model rancangan PTK dari para ahli. Selama ini dikenal berbagai model PTK, namun pada dasarnya terdapat empat tahap yang harus dilalui yaitu (1) perencanan (planning), (2) pelaksanaan (acting), (3) pengamatan (observing), dan (4) refleksi (reflecting). Keempat tahap tersebut merupakan satu siklus dan akan dapat berlanjut kepada siklus kedua, siklus ketiga dan seterusnya sesuai dengan apa yang diinginkan dalam penelitian.

Untuk penelitian ini penulis memilih rancangan penelitian tindakan yang disampaikan Mc. Kernan seperti terlihat pada gambar berikut.

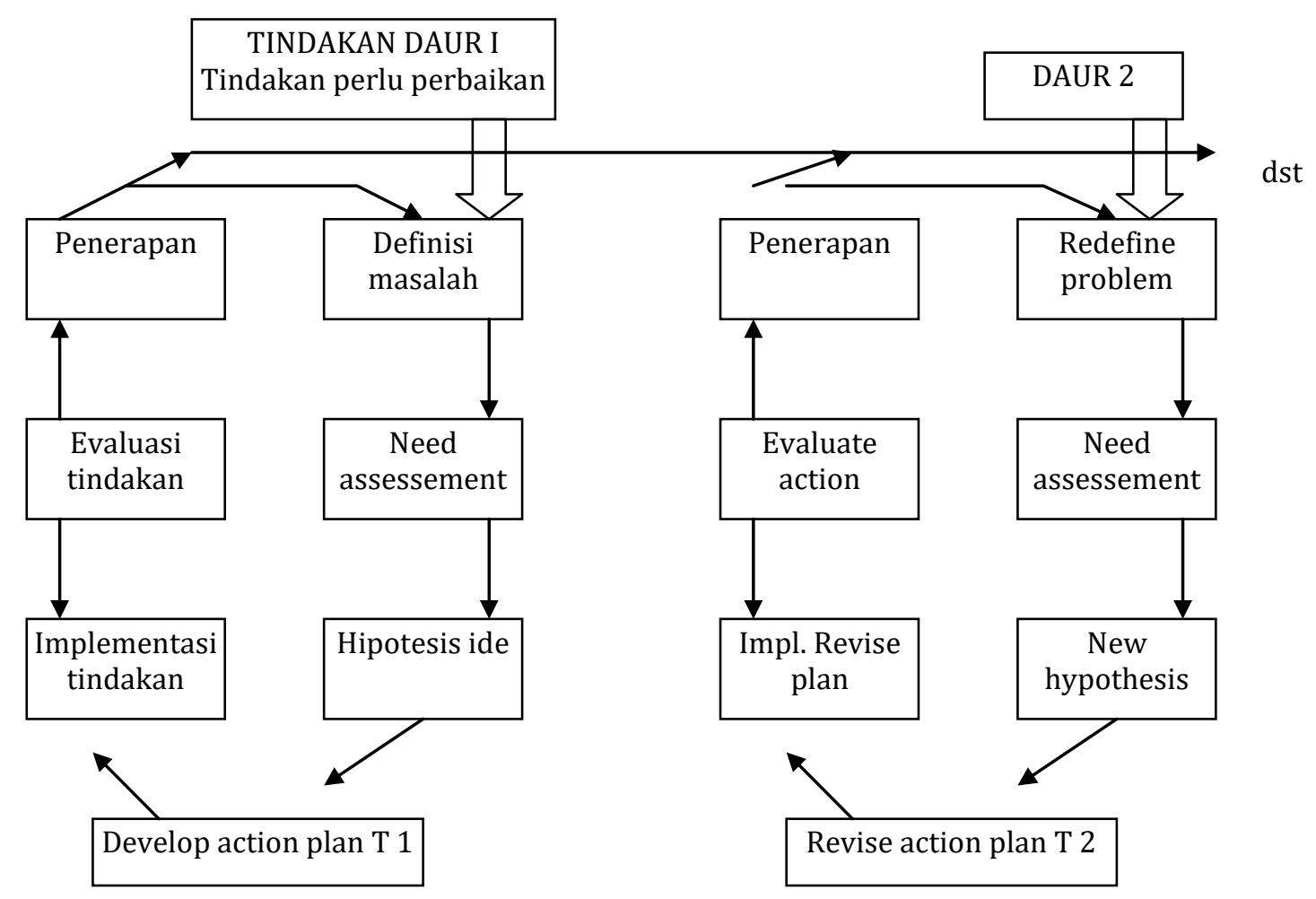

Gambar 1 . Penelitian Tindakan Model Mc. Kernan, 1991 (dalam Sukidin, Basrowi, Suranto, 2002: 54) 
Prosedur: Tindakan daur I dilakukan definisi masalah dilanjutkan dengan pelaksanaan di lapangan, dirumuskan hipotesisnya, dikembangkan hipotesis tersebut, diimplementasikan, dievauasi dari hasil yang didapat dan evaluasi diterapkan. Langkah-langkah pada daur II atau siklus II sama dengan yang di siklus I yaitu dimulai dengan adanya suatu permasalahan yang baru, didefinisikan masalahnya, dibuat hipotesisnya direvisi, selanjutnya dialkukan implementasi di lapangan, dievaluasi, kemudian hasil yang didapat merupakan penerapanbaru apabila masih adalah masalah.

Pengumpulan data dalam penelitian ini menggunakan tes prestasi belajar. Tes prestasi belajar berupa tes soal isian maupaun esay. Untuk menganalisis data hasil penelitian ini digunakan metode deskriptif. Untuk data kuantitatif dianalisis dengan mencari mean, median, modus, membuat interval kelas dan melakukan penyajian dalam bentuk tabel dan grafik.

Indikator keberhasilan penelitian yang diusulkan dalam penelitian ini pada siklus I dan II mencapai nilai rata-rata 75,00 dengan ketuntasan belajar 85\%. dengan KKM yang ditetapkan untuk mata pelarajan PKN pada SD Negeri 2 Kenderan adalah 73.

\section{Hasil dan Pembahasan}

1. Hasil yang diperoleh dari kegiatan awal:

Data pada awal pembelajaran baru memperoleh nilai rata-rata 68,09 dengan siswa yang tuntas hanya 10 (47,61\%) dan yang tidak tuntas tuntas ada 11 orang (52,38\%) hal ini masih jauh dari harapan tujuan pembelajaran yang ingin dicapai yaitu 85\%. Hasil pada awal pembelajaran ini masih sangat jauh dari harapan hal ini terjadi karena guru belum menggunakan model pembelajaran dan RPP masih bersifat konvensional. Untuk meninggkatkan prestasi belajar siswa kelas VI semester II SD Negeri 2 Kenderan tahun pelajaran 2017/2018 maka sangat perlu dilakukan perbaikan pembelajaran dengan menggunakan model pembelajaran Problem Solving pada siklus I.

\section{Hasil pada siklus I:}

Pada siklus I sudah diupayakan untuk perbaikan pembelajaran untuk meningkatkan prestasi belajar Matematika dengan menggunakan model pembelajaran Problem Solving. Peneliti telah giat melakukan kegiatan yang susuai dengan kebenaran teori yang ada sehingga peneliti memperoleh hasil yang lebih baik dari proses awal, yaitu dengan rata-rata nilai 72,61 dari jumlah nilai secara klasikal 1525 seluruh siswa di kelas VI, dan prosentase ketuntasan belajarnya adalah 67,64\%, yang tidak tuntas adalah $66,66 \%$. Hasil ini belum maksimal, karena belum mecapai indikator keberhasilan penelitian yang mencanangkan dengan minimal prosentase ketuntasan belajar $85 \%$.

\section{Pada siklus II ,}

Dengan tindakan yang sangat maksimal dan pelaksanaan yang betul-betul mengikuti kebenaran teori sesuai dengan model pembelajaran Problem Solving dalam pembelajaran Matematika di kelas VI SD Negeri 2 Kenderan, dimana hasil yang diperoleh pada siklus II ini ternyata prestasi belajar Matematika meningkat secara signifikan setelah menggunakan langkah-langkah model pembelajaran Problem Solving dengan maksimal dengan nilai rata-rata 80,95 dan ketuntasan belajarnya adalah 90,47\%. Dari keseluruhan jumlah siswa yaitu 21orang siswa 19 orang siswa telah mampu melampaui nilai KKM yaitu 73. Semua hasil yang diperoleh dari awal, siklus I dan siklus II dipaparkan dalam bentuk tabel dan grafik seperti berikut:

Tabel 1 : Tabel Data Prestasi Belajar Siswa kelas VI SD Negeri 2 Kenderan

\begin{tabular}{llllll}
\hline DATA & AWAL & SIKLUS I & SIKLUS II & VARIABEL & Belajar \\
\hline Skor Nilai & 1430 & 1525 & 1700 & Prestasi & Matematika \\
Rata Rata Kelas & 68,09 & 72,61 & 80,95 & Dengan \\
Persentase & $47,61 \%$ & $66,66 \%$ & $90,47 \%$ & KKM = 73 \\
Ketuntasan & & & & \\
\hline
\end{tabular}




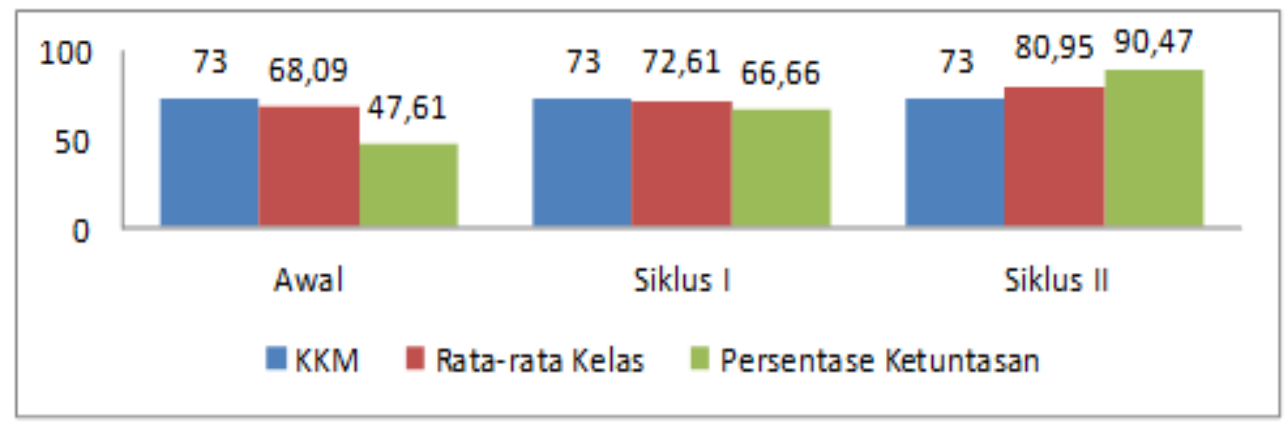

Gambar 1. Grafik Histogram Prestasi Belajar Matematika siswa kelas VI semester II tahun pelajaran 2017/2018 SD Negeri 2 Kenderan

Hasil tes prestasi belajar yang merupakan tes isian dan esay memforsir siswa untuk betul-betul dapat memahami apa yang sudah dipelajari. Nilai rata-rata siswa di siklus I sebesar 72,61 menunjukkan bahwa siswa setelah menguasai materi yang diajarkan walaupun belum begitu sempurna. Hasil ini menunjukkan peningkatan kemampuan siswa menguasai mata pelajaran Matematika. Apabila dibandingkan dengan nilai awal siswa sesuai data yang sudah disampaikan dalam analisis sebelumnya.

Hasil tes prestasi belajar di siklus I telah menemukan efek utama bahwa penggunaan model/metode tertentu akan berpengaruh terhadap prestasi belajar siswa yang dalam hal ini adalah model Problem Solving Hal ini sesuai dengan hasil meta analisis metode pembelajaran yang dilakukan oleh Soedomo (dalam Puger, 2004) yang menyatakan bahwa model/metode pembelajaran yang diterapkan oleh seorang guru berpengaruh terhadap prestasi belajarnya.

Seperti telah diketahui bersama bahwasannya mata pelajaran Matematika menitikberatkan pembelajaran pada aspek kognitif, afektif, dan psikimotorik sebagai pedoman prilaku kehidupan seharihari siswa. Untuk penyelesaian kesulitan yang ada maka penggunaan model/metode ini dapat membantu siswa untuk bertindak aktif, keratif,inovatif, dan mandiri. memecahkan masalah yang ada bersama dengan anggota kelompok diskusinya. Hal inilah yang membuat siswa berpikir lebih tajam, lebih kreatif dan kritis sehingga mampu untuk memecahkan masalah-masalah yang kompleks dan efek selanjutnya adalah para siswa akan dapat memahami dan meresapi mata pelajaran Matematika lebih jauh.

Kendala yang masih tersisa yang perlu dibahas adalah prestasi belajar yang dicapai pada siklus I ini belum memenuhi harapan sesuai dengan tuntutan KKM mata pelajaran Matematika di sekolah ini yaitu 73. Oleh karenanya upaya perbaikan lebih lanjut masih perlu diupayakan sehingga perlu dilakukan perencanaan yang lebih matang untuk siklus selanjutnya.

Hasil yang diperoleh dari tes prestasi belajar di siklus II menunjukkan bahwa kemampuan siswa dalam mengikuti pelajaran sudah cukup baik. Ini terbukti dari rata-rata nilai siswa mencapai 80,95. Hasil ini menunjukkan bahwa model Problem Solving telah berhasil meningkatkan prestasi belajar bidang studi Matematika siswa kelas VI SD Negeri 2 Kenderan.

Hasil penelitian ini membuktikan bahwa model/metode yang diterapkan dalam proses pembelajaran berpengaruh secara signifikan terhadap prestasi belajar siswa. Prestasi yang dicapai siswa membuktikan bahwa guru sudah tepat memilih model/metode dalam melaksanakan proses pembelajaran.

Setelah dilakukan tindakan dalam dua siklus dapat dilihat perbandingan nilai rata-rata yang diperoleh, dimana pada awalnya nilai rata-rata siswa hanya 68,09 naik di siklus I menjadi 72,61 dan di siklus II naik menjadi 80,95. Kenaikan ini merupakan upaya maksimal yang peneliti laksanakan untuk meningkatkan prestasi belajar siswa terutama meningkatkan mutu pendidikan di SD Negeri 2 Kenderan.

Hasil penelitian ini sejalan dengan hasil penelitian yang dilakukan oleh Tampubolon dan Sondang (2013) dengan judul Pengaruh Model Pembelajaran Problem Solvingterhadap Hasil Belajar Siswa Kelas X SMA Negeri 7 Medan. Dari hasil analisa data, diperolehnilai rata-rata aktivitas siswa kelaseksperimen 68,12 dan kelas kontrol 52,92, ini menunjukkan bahwa modelpembelajaranproblem solvinglebih meningkatkan aktivitas belajar siswa.Setelahdiberi perlakuan berbeda diperoleh rata-rata nilai postes pada kelas eksperimen 68,20 dan kelas kontrol 58,00. Hasil pengujian hipotesis (uji t) diperoleh $t$ hitung $>$ t tabel yaitu 2,06 $>1,66$ dengan $\alpha=0,05$, ini berarti bahwa ada pengaruh model pembelajaran problem solving terhadap hasil belajar siswa.

Penelitian Listiani, Ara, dan Meti (2017) dengan judul Perbandingan Model Pembelajaran Problem Solving dan Problem Based Learning Terhadap Hasil Belajar Siswa Pada Materi Sistem Reproduksi Manusia (Penelitian pada Siswa Kelas XI IPA SMAN 1 Ciparay Kab. Bandung). Dari hasil penelitian 
diperoleh data pada kelas eksperimen 1 yang menggunakan model pembelajaran Problem Solving menunjukkan nilai rata-rata pretest 45,88 dan nilai ratarata posttest 76,50 , sedangkan pada kelas eksperimen 2 yang menggunakan model pembelajaran Problem Based Learning rata-rata pretest 45,12 dan nilai rata-rata posttest 64,75. Setelah dilakukan posttest dilanjutkan dengan uji t dan diperoleh hasil signifikan, karena thitung> ttabel pada taraf $\alpha=0,05 \%$, yakni 5,98 $>1,99$, maka H0 ditolak dan Ha diterima. Berdasarkan hasil penelitian dapat disimpulkan bahwa hasil belajar siswa yang menggunakan model Problem Solving lebih baik dibandingkan dengan model Problem Based Learning pada materi sistem reproduksi manusia.

\section{Simpulan Dan Saran}

Berdasarkan penelitian yang telah dilakukan, dapat ditarik simpulan sebagai berikut. Prestasi Belajar Matematika dapat ditingkatkan secaara efektif melalui penggunaan model pembelajaran Problem Solving pada siswa kelas VI SD Negeri 2 Kenderan Semester II Tahun Pelajaran 2017/2018.

Saran yang dapat disampaikan dari hasil penelitian ini adalah:

1. Bagi Guru Matematika, apabila mau melaksanakan proses pembelajaran penggunaan model/metode yang telah diterapkan ini semestinya menjadi pilihan dari beberapa model/metode yang ada mengingat model/metode ini telah terbukti dapat meningkatkan prestasi belajar siswa.

2. Bagi peneliti lain, walaupun penelitian ini sudah dapat membuktikan efek utama dari model/metode Problem Solving dalam meningkatkan prestasi belajar, sudah pasti dalam penelitian ini masih ada halhal yang belum sempurna dilakukan, oleh karenanya disarankan kepada peneliti lain yang berminat meneliti topik yang sama untuk meneliti bagian-bagian yang tidak sempat diteliti.

3. Bagi pengembang pendidikan, selanjutnya untuk adanya penguatan-penguatan, diharapkan bagi peneliti lain untuk melakukan penelitian lanjutan guna memverifikasi data hasil penelitian ini.

\section{Daftar Rujukan}

Arief Furchan. 2004. Pengantar Penelitian dalam Pendidikan. Pustaka Belajar: Yogyakarta.

Arikunto, Suharsimi; Suhardjono; Supardi. 2006. Penelitian Tindakan Kelas. Jakarta: PT Bumi Aksara.

Aunurrahman. 2009. Belajar dan Pembelajaran. Bandung: Alfabeta.

Azwar, Saifuddin. 2003. Penyusunan Skala Psikologi. Yogyakarta: PustakaPelajar.

Badan Standar Nasional Pendidikan.2007.Peraturan Menteri Pendidikan Nasional Republik Indonesia Nomor 41 Tahun 2007.Jakarta: BSNP.

Basrowi dan Sukidin. 2002. Metode Penelitian Kualitatif Perspektif Mikro. Surabaya. Insan Cendikia.

Dahar, Ratna Wilis. 1989. Teori-Teori Belajar. Jakarta: Penerbit Erlangga.

Depdiknas. 2009. Kompetensi Supervisi Akademik. Direktorat Tenaga Kependidikan, Direktorat Jendral Peningkatan Mutu Pendidikan Tenaga Kependidikan.

Djamarah, Syaiful Bahri, 2006. Strategi Belajar Mengajar. Jakarta : PT Rineka. Cipta.

Gulo, W. 2002. Metode Penelitian. Jakarta: PT. Grasindo.

Listiani, Rika, Ara Hidayat, dan Meti Maspupah. 2017. Perbandingan Model Pembelajaran Problem Solving dan Problem Based Learning Terhadap Hasil Belajar Siswa Pada Materi Sistem Reproduksi Manusia (Penelitian pada Siswa Kelas XI IPA SMAN 1 Ciparay Kab. Bandung). Jurnal Program Studi Pendidikan Biologi, Februari 2017, Vol. 7, No. 1

Sirait, Erlando Doni . Pengaruh Minat Belajar Terhadap Prestasi Belajar Matematika . Jurnal Formatif 6(1): 35-43, 2016 
Syafi'I, Ahmad. 2018. Studi Tentang Prestasi Belajar Siswa Dalam Berbagai Aspek Dan Faktor Yang Mempengaruhi . Jurnal Komunikasi Pendidikan, Vol.2 No.2, Juli 2018

Tampubolon, Togi dan Sondang Fitriani Sitindaon. 2013. Pengaruh Model Pembelajaran Problem Solvingterhadap Hasil Belajar Siswa Kelas X SMA Negeri 7 Medan. Jurnal INPAFI Volume 1, Nomor 3.

Wijayanti, Takdir Sukmo . 2014. Meningkatkan Minat Dan Prestasi Belajar Matematika Dengan Model Pembelajaran Group Investigation Siswa Kelas Vii A Smp Negeri 1 Polanharjo Klaten . Jurnal Pendidikan Matematika Vol 2 No 1, November 2014. 